\title{
PEDESTRIAN MORTALITY TRENDS IN CHILDREN OVER FOUR DECADES IN TRANSITIONAL LITHUANIA
}

\author{
Birutė Strukčinskienė ${ }^{1}$, Robert Bauer ${ }^{2}$, Sigitas Griškonis ${ }^{3,1}$, Vaiva Strukčinskaitė \\ ${ }^{1}$ Klaipeda University, Faculty of Health Sciences, Klaipeda, Lithuania, \\ ${ }^{2}$ Austrian Road Safety Board (KFV), Vienna, Austria, \\ ${ }^{3}$ Klaipeda University Hospital, Klaipeda, Lithuania, \\ ${ }^{4}$ Vilnius University, Faculty of Medicine, Vilnius, Lithuania
}

Key words: pedestrian, mortality, trends, children, young people, transitional Lithuania.

\begin{abstract}
Summary
The aim of the study was to examine the long-term trends in pedestrian mortality for children (aged 0 to 14 years) and young people (aged 15 to 19 years) over four decades in transitional Lithuania.

Methods. Road traffic fatality data were obtained from Statistics Lithuania and the Archives of Health Information Centre. Trends were analysed by linear regression using "Independence" as a slopechanging intervention in 1991 and population as a further explanatory factor in structural time series models.

Results. The impact of the interventions, along with the reforms and changes related with the Independence, on pedestrian fatality trends in our time series model was found highly statistically significant for children 0 to 14 years $(\mathrm{p}<0.001)$ and still significant for young people 15 to 19 years $(p<0.05)$. No significant impact on the trend of road traffic deaths was found for the "control-groups" of non-pedestrian road users in the age group 0 to 14 years and adult pedestrians (over 19 years of age). For the age group 15 to 19 years the effect of reforms was also significant for non-pedestrians $(\mathrm{p}<0.05)$. These results indicate that the effect of measures and changes used in the post-independence period was more specific in children that participated in road traffic as pedestrians than in adult pedestrians, or in nonpedestrian road users.

Conclusions. Pedestrian deaths in Lithuania fell significantly in the age groups $0-14$ and $15-19$ years. A declining trend was found in road traffic fatalities
\end{abstract}

and in pedestrian deaths in transitional Lithuania in the post-independence period. Socioeconomic and political transformations, systematic reforms in healthcare along with sustainable preventive measures may have contributed to this decrease. Targeted road safety measures were road traffic regulations, pedestrian education and environmentally based prevention measures. As child pedestrians are the most vulnerable group of road users, continued road safety education and promotion are recommended in order to maintain this trend, and to involve adult pedestrians in this development.

\section{Introduction}

Worldwide over 1.2 million people die each year from road traffic crashes, and between 20 and 50 million suffer from non-fatal injuries. Nearly half of those dying on the world's road are vulnerable road users [1]. The global economic burden of motor vehicle collisions and pedestrian injuries approximates $\$ 500$ billion [2]. In some low-income and middle-income countries up to $80 \%$ of road traffic deaths are among vulnerable road users [1].

In the European Union (EU) 50,000 fatal road traffic injuries occur per year; one-third of those killed are vulnerable road users (pedestrians, cyclists, two-wheelers). Among 4.3 million non-fatal road injuries treated in hospitals per year in the EU, two-thirds were vulnerable road users. In the EU, pedestrian deaths account on average for $19 \%$ of road traffic deaths [3]. Pedestrians, cyclists and motorised two-wheelers are the most vulnerable road users because they are at the highest risk of death or severe injuries in case of transport crashes and collisions. Children in particular are one of the main groups at risk of having a fatal or severe injury as pedestrians or cyclists. For each mile travelled, there are about 30 times more child pedestrian 
deaths than there are deaths to child car occupants [5].

In the EU, Lithuania shows the highest percentage of pedestrian fatalities (37\%) among all road traffic deaths for the whole population $[3,4]$ and high rates of traffic injury mortality rates overall [6]. Child traffic injury rates are still much higher in Lithuania than in other European countries $[7,8,9]$. The previous studies were focused on the age groups and not the type of road user. Furthermore, it is not thoroughly documented how transitional economic and social conditions have influenced traffic injury mortality in children and young people in Lithuania before and after the Independence from the former USSR in 1991.

The objective of this paper was to examine trends in pedestrian mortality for children and young people compared to the overall trends in road traffic mortality between two periods in transitional Lithuania: pre-independence 1971 to 1990, and post-independence 1991 to 2011. Changes in trends were placed in relation with road safety measures in Lithuania in the respective period.

\section{Materials and Methods}

The data for this study were obtained from the Department of Statistics for the Government of the Republic of Lithuania and the Archives of the Health Information Centre. The time series of road traffic fatalities of children aged 0-14 years, young people aged 15-19 and all age groups over the years 1971 to 2011 were examined using the statistical / econometric software system STAMP Version 6.2. STAMP (Structural Time Series Analyser, Modeller and Predictor) is a menu-driven system designed to model, describe and predict time series, based on structural time series models. These models are set up in terms of components such as trends, seasons and cycles that have a direct interpretation [10]. The hypothesis for the statistical analysis of the pedestrian mortality data for Lithuania was, that there was a change of trend between the periods 1971-1990 and 1991-2011; in particular, a decline in pedestrian mortality triggered by the changes after the Independence in 1991.

The approach for the STAMP analysis was to use a simple linear regression model for pedestrian fatalities in the age group 0 to 14 years for the whole period. "Independence" was introduced as a slope changing intervention in 1991 and population added as a further explanatory factor (covariate), whereby the number of children aged 0-14 years in Lithuania dramatically decreased after the Independence, from 845000 in 1991 to 488000 in 2011).

The symbolic equation of the model is:

Fatalities $=$ Trend + Population + Intervention + Irregular

Fatalities: estimated number of fatalities (for a given year)
Trend: estimated number of fatalities according to the parameters level and slope (fixed and/or stochastic)

Population: a factor for the number of population for a given year

Intervention: a factor for the parameter slope before and after Independence in 1991 (value of 0 for all years before 1991, and 1 for 1991 and all years after 1991)

Irregular: the error or noise component of the model

The model performance was assessed for the options fixed versus stochastic for the parameters level and slope of the "regression line" using the Coefficient of Determination (r-square), the Prediction Error Variance (p.e.v) and the Information Criterion of Akaike (AIC). The model with fixed level and slope, which equals the classical regression analysis, was found to have a slightly better performance $(\mathrm{r}$-square $=0.88$, p.e.v $=27.33, \mathrm{AIC}=3.50)$. $)$ than the other options (next best options, stochastic level and fixed slope: $r$-square $=0.86$, p.e.v $=31.63, \mathrm{AIC}=3.70$ ). Thus, this model was then applied to all groups of fatalities under investigation.

It was not the purpose of the statistical analysis to propose a specific model for the evolution of fatalities for a particular group of road users, or to predict this evolution for the years to come. Hence, the significance level of the intervention factor "Independence 1991" was considered the main criteria for differences in fatality trends between the periods 1971-1990 and 1991-2011 among various groups of road users--pedestrians and non-pedestrians by gender, and three age groups.

Data on age groups, gender and number of children and young people deceased in road traffic crashes as pedestrians were based on the International Classification of Diseases (ICD). The classification system has changed numerous times during the long study period, from code 161 in ICD-8 for 1971-1987 to code 161 for an abridged version of ICD-9 in 1988-1992, followed by code E 814 in 1993-1997 from the full version of ICD-9. From 1998 to 2010 code V01-V09 was used from the ICD-10. Starting 2011, codes V00-09 from the ICD-10-AM (an Australian modification of ICD-10) were introduced in the country.

The Bioethics Committee of Lithuania approved of the study.

\section{Results}

During the observation period before the Independence (1971 to 1990) the number of children aged 0 to 14 years in Lithuania that died as pedestrians in road traffic crashes ranged from 34 to 58 per year; during the 20 -year period after the Independence (1991 to 2011) this range was 3 to 47. The respective ranges for adolescents aged 15 to 19 years 
were 8 to 31 pedestrian fatalities before and 4 to 17 after the Independence (Table 1).

Visual inspection of the time series of these fatality numbers indicates that a declining trend set in after the Independence in 1991, at varying degrees for different age groups and road users (Figure 1 and Figure 2). The trend was most prominent for child-pedestrians aged 0 to 14 years (Figure 1) and pedestrians aged 15 to 19 years (Figure 2) compared to non-pedestrian road users aged 0 to 14 and pedestrians over 14 years (Figure 1). The comparison of

Table 1. Pedestrian deaths in children and young people in Lithuania, 1971 -2011

\begin{tabular}{|c|c|c|c|c|c|c|c|c|c|}
\hline \multirow[t]{3}{*}{ Year } & \multicolumn{9}{|c|}{ Age group } \\
\hline & \multicolumn{3}{|c|}{$0-14$} & \multicolumn{3}{|c|}{$15-19$} & \multicolumn{3}{|c|}{$0-19$} \\
\hline & Male & Female & Total & Male & Female & Total & Male & Female & Total \\
\hline 1971 & 24 & 15 & 39 & 9 & 6 & 15 & 33 & 21 & 54 \\
\hline 1972 & 24 & 19 & 43 & 8 & 2 & 10 & 32 & 21 & 53 \\
\hline 1973 & 25 & 16 & 41 & 6 & 2 & 8 & 31 & 18 & 49 \\
\hline 1974 & 27 & 12 & 39 & 10 & 9 & 19 & 37 & 21 & 58 \\
\hline 1975 & 26 & 19 & 45 & 12 & 4 & 16 & 38 & 23 & 61 \\
\hline 1976 & 21 & 17 & 38 & 12 & 6 & 18 & 33 & 23 & 56 \\
\hline 1977 & 25 & 20 & 45 & 13 & 2 & 15 & 38 & 22 & 60 \\
\hline 1978 & 24 & 14 & 38 & 17 & 7 & 24 & 41 & 21 & 62 \\
\hline 1979 & 21 & 14 & 35 & 15 & 8 & 23 & 36 & 22 & 58 \\
\hline 1980 & 23 & 22 & 45 & 13 & 8 & 21 & 36 & 30 & 66 \\
\hline 1981 & 23 & 11 & 34 & 10 & 2 & 12 & 33 & 13 & 46 \\
\hline 1982 & 23 & 17 & 40 & 12 & 7 & 19 & 35 & 24 & 59 \\
\hline 1983 & 33 & 18 & 51 & 16 & 4 & 20 & 49 & 22 & 71 \\
\hline 1984 & 34 & 24 & 58 & 22 & 9 & 31 & 56 & 33 & 89 \\
\hline 1985 & 25 & 21 & 46 & 15 & 6 & 21 & 40 & 27 & 67 \\
\hline 1986 & 27 & 23 & 50 & 9 & 6 & 15 & 36 & 29 & 65 \\
\hline 1987 & 26 & 12 & 38 & 8 & 6 & 14 & 34 & 18 & 52 \\
\hline 1988 & 27 & 14 & 41 & 10 & 6 & 16 & 37 & 20 & 57 \\
\hline 1989 & 23 & 18 & 41 & 17 & 5 & 22 & 40 & 23 & 63 \\
\hline 1990 & 25 & 13 & 38 & 9 & 3 & 12 & 34 & 16 & 50 \\
\hline 1991 & 28 & 19 & 47 & 9 & 3 & 12 & 37 & 22 & 59 \\
\hline 1992 & 26 & 16 & 42 & 11 & 6 & 17 & 37 & 22 & 59 \\
\hline 1993 & 23 & 15 & 38 & 10 & 5 & 15 & 33 & 20 & 53 \\
\hline 1994 & 22 & 13 & 35 & 10 & 5 & 15 & 32 & 18 & 50 \\
\hline 1995 & 14 & 12 & 26 & 10 & 3 & 13 & 24 & 15 & 39 \\
\hline 1996 & 16 & 15 & 31 & 7 & 8 & 15 & 23 & 23 & 46 \\
\hline 1997 & 9 & 7 & 16 & 4 & 2 & 6 & 13 & 9 & 22 \\
\hline 1998 & 16 & 12 & 28 & 11 & 3 & 14 & 27 & 15 & 42 \\
\hline 1999 & 12 & 8 & 20 & 5 & 8 & 13 & 17 & 16 & 33 \\
\hline 2000 & 8 & 5 & 13 & 8 & 2 & 10 & 16 & 7 & 23 \\
\hline 2001 & 14 & 7 & 21 & 6 & 2 & 8 & 20 & 9 & 29 \\
\hline 2002 & 7 & 4 & 11 & 11 & 5 & 16 & 18 & 9 & 27 \\
\hline 2003 & 7 & 2 & 9 & 5 & 6 & 11 & 12 & 8 & 20 \\
\hline 2004 & 6 & 2 & 8 & 7 & 0 & 7 & 13 & 2 & 15 \\
\hline 2005 & 9 & 4 & 13 & 8 & 3 & 11 & 17 & 7 & 24 \\
\hline 2006 & 7 & 7 & 14 & 8 & 4 & 12 & 15 & 11 & 26 \\
\hline 2007 & 7 & 1 & 8 & 7 & 3 & 10 & 14 & 4 & 18 \\
\hline 2008 & 7 & 2 & 9 & 7 & 2 & 9 & 14 & 4 & 18 \\
\hline 2009 & 3 & 0 & 3 & 5 & 2 & 7 & 8 & 2 & 10 \\
\hline 2010 & 3 & 1 & 4 & 6 & 1 & 7 & 9 & 2 & 11 \\
\hline 2011 & 5 & 2 & 7 & 3 & 1 & 4 & 8 & 3 & 11 \\
\hline
\end{tabular}


Table 2. Levels of significance of parameters "Independence in 1991" (intervention) and "Population" (covariate) for the STAMP model "Log-Fatalities $=$ Trend + Population + Intervention + Irregular"

$* p$-value $<0.05$

\begin{tabular}{|l|c|c|}
\hline & \multicolumn{2}{|c|}{ p-values for model predictors } \\
\hline Log Fatalities Subset & Population & $\begin{array}{c}\text { Indepen- } \\
\text { dence }\end{array}$ \\
\hline Pedestrian 0-14 & 0.9423 & $0.0032^{*}$ \\
\hline Pedestrian 0-14 male & 0.4297 & $0.0003^{*}$ \\
\hline Pedestrian 0-14 female & 0.3096 & 0.0908 \\
\hline Non-Pedestrian 0-14 & 0.1338 & 0.5926 \\
\hline Pedestrian >14 & 0.0544 & 0.9747 \\
\hline Pedestrian 15-19 & $0.0077^{*}$ & $0.0031^{*}$ \\
\hline Pedestrian 15-19 male & $0.0025^{*}$ & $0.0241^{*}$ \\
\hline Pedestrian 15-19 female & 0.2836 & $0.0119^{*}$ \\
\hline Non-Pedestrian 15-19 & $0.0001^{*}$ & $0.0043^{*}$ \\
\hline Pedestrians > 19 & 0.8140 & 0.1972 \\
\hline
\end{tabular}

adolescents aged 15 to 19 years with respective "control groups" yields a similar but less distinct pattern (Figure 2). Figures 3 and 4 show the results of the time series approach (STAMP model) (Figure 3, Figure 4) for child and adolescent pedestrian fatalities from 1971 to 2011 (log-transformed data; see also Table 2).

Table 2 summarizes the results of the STAMP fatalities analysis for all given sub-groups of age, sex and type of road user; for the control-groups of non-pedestrians and pedestrians over 19 years of age. The impact of the predictor "Independence in 1991" and related changes and reforms in the country on pedestrian fatality trends was found highly significant for both genders combined, and less significant for girls 0 to 14 years (males $\mathrm{p}<0.01$, fema-

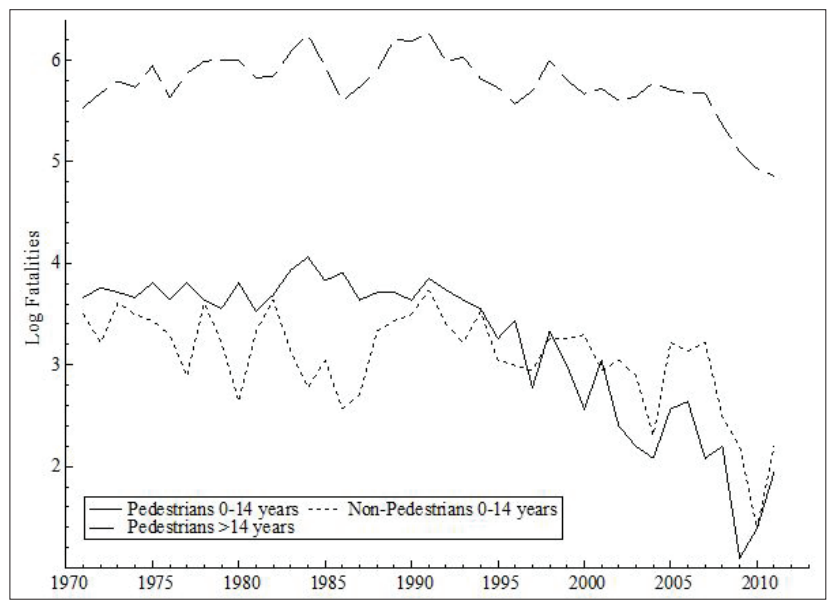

Figure 1. Comparison of the time series of fatalities of pedestrian and non-pedestrian road users, 0 to 14 years and over 14 years. For ease of comparison, the log of the fatality numbers is shown les $\mathrm{p}<0.1$ ). Also for the whole group of pedestrians aged 15 to 19 years, and for each sex as well, the intervention proved to be significant $(p<0.001$ for the whole group, $p<0.05$ for each sex). For the age group 15 to 19 the effect of the Independence, along with the measures and reforms in the post-independence period was also highly significant for non-pedestrians $(\mathrm{p}<0.01)$.

No significant impact of the reforms and activities related with the Independence on the trend of road traffic deaths was found for non-pedestrian road users in the age group 0 to 14 and adult pedestrians (over 19 years of age; Table 2). Again, with the exception of non-pedestrian adolescents (15 to 19 years), the quantitative statistical analysis indicates that the effect of the interventions related with the Independence was more specific in children and young people that participated in road traffic as pedestrians than in pedestrians of other age groups, or non-pedestrian road users of the same age group.

\section{Discussion}

A declining trend was found in road traffic fatalities in Lithuania after the Independence in 1991, of varying degrees for different age groups and road users, namely for children 0-14 years of age and pedestrians. During the study period, Lithuania went through significant political, social and economic changes. This includes the independence from the Soviet Union in 1991, joining the European Union in 2004 and changing from a low-income to middleincome country. At the macro-level, the Lithuanian reforms to transition from a socialist to a market economy system were more sustainable and systematic than in other former Soviet neighbourhood republics of Russia or Belorussia.

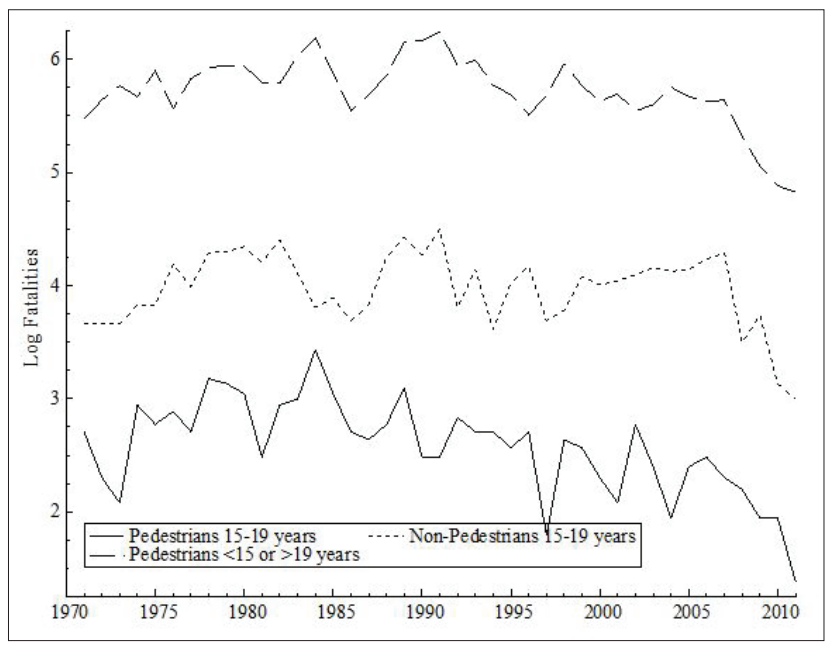

Figure 2. Time series of adolescent pedestrian and non-pedestrian fatalities 
In addition, Lithuania experienced a sharp drop in per capita income during economic recession in 1990, but managed to recover early $[11,12]$.

Legal, environmental and educational road safety measures were implemented after the Independence to systematically address road safety. These include Road Traffic Regulations in 1994, Road Traffic Safety Law in 2000, and the establishment of the National Road Safety Commission in 1997. That has full control over the implementation of Road Safety Policy in Lithuania and a coordinated National Road Safety Programme since 2000. There were observed improvement of vehicle safety, engineering measures of traffic safety enhancement (for instance, traffic-calming equipment, speeding cameras, and road modernization), and legislative reforms (driving under the influence, seat belt usage in the front and back seats, child restraints, speed reduction, alcohol control policy, and graduating driver-licensing systems). Lithuania reported the implementation of $56 \%$ of effective interventions for road traffic injury prevention (regional median score - 81\%), and there is national policy for road safety for all age groups in the country $[9,13]$. Investments have also been made in a longterm road safety promotion strategy for children and young people, including an annual national traffic safety training competition and courses at the university and secondary level for increased awareness of child injury prevention and road safety in the country.

Death rates have declined significantly for child pedestrians aged 0-14 years in other parts of Europe (namely England and Wales), in Australia, and in the United States $[5,15,16]$. Explanations cited include progress in emergency and medical care and reduced walking $[5,16]$. In addition, although the study does not have trend data on exposure to walking by children in Lithuania in pre-independence period, we do know that motorisation has steadily risen since 1991 [17], and children are driven to school by their parents more frequently.

Lithuanian healthcare reforms resulting in improved medical treatment, high-level intensive care equipment usage and professional rehabilitation may have also contributed to the significant

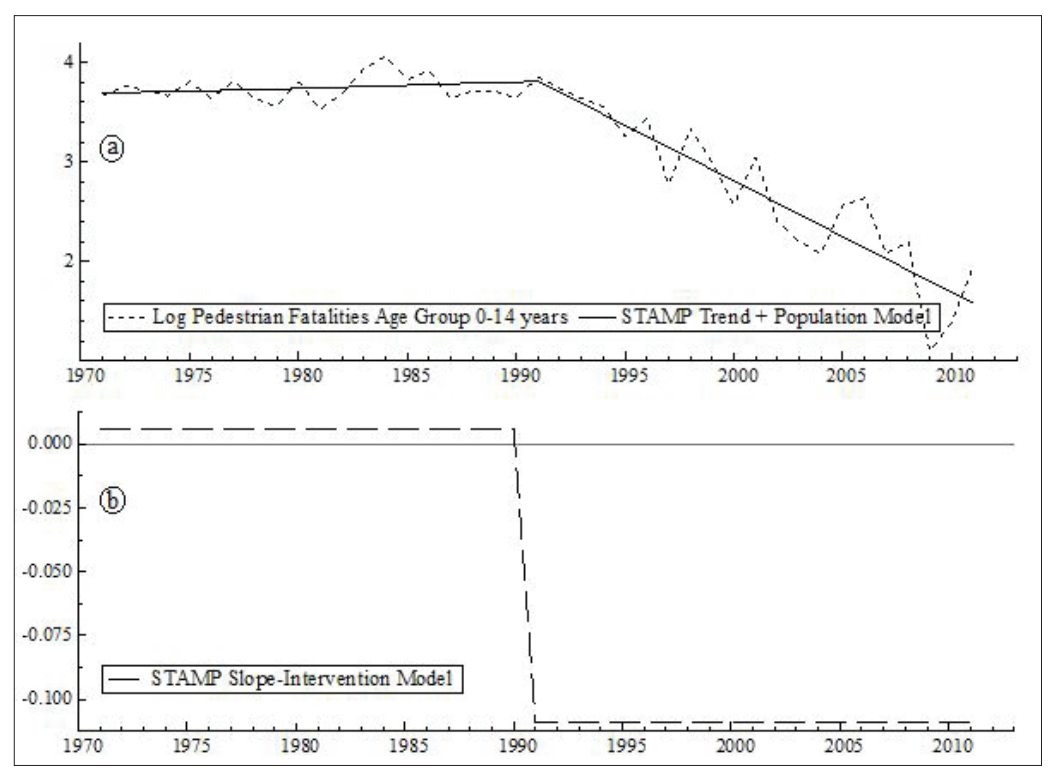

Figure 3. (a) STAMP time series model (full line) of log-transformed fatalities of child-pedestrians aged 0 to 14 years in Lithuania 1971 to 2011 (dotted line), and "Independence in 1991" as the point of intervention. (b) Slope change induced by the intervention variable "Independence in 1991" (coefficient -0.116 , t-value $-3.137[\mathrm{df}=39, \mathrm{p}=0.0032])$

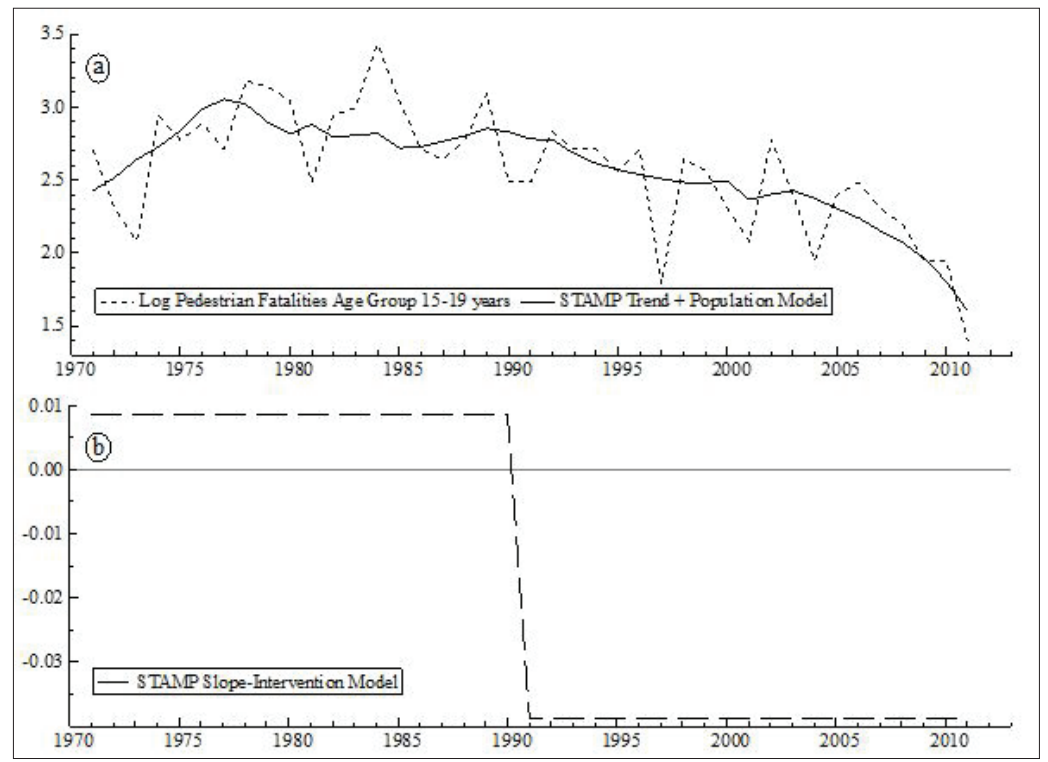

Figure 4. (a) STAMP time series model (full line) of fatalities of adolescent pedestrians aged 15 to 19 years in Lithuania 1971 to 2011 (dotted line), using the year 1991 as a point of intervention ("Independence in 1991") and the respective population numbers as a covariate. (b) Slope change induced by the intervention variable "Independence in 1991" (coefficient -0.047 , t-value -3.16 [d=39, p=0.0031]) 
reduction in child pedestrian deaths. Key reforms in healthcare in Lithuania included Health System Law (1994), Healthcare Institutions Law (1996), and Public Health Law (2002). Health reforms in Lithuania after regaining independence were shaped by a number of policy documents. The key document, the National Health Concept, outlined new approaches to healthcare, prioritizing disease prevention and developing primary care. Another core document, the Lithuanian Health Programme introduced a set of three major objectives for population health: (1) to reduce mortality and increase average life expectancy, (2) to improve quality of life, and (3) to increase health equity. The programme covered major health issues, including injuries, non-communicable diseases, and risk factors, with a particular focus on reduction of alcohol and tobacco consumption and drug abuse. The Primary Healthcare Development Strategy was prepared in 1995 with the aim of strengthening and expanding the role of primary care and focusing on prevention. Lithuania's Health Programme was launched in 1998, introducing a concept of public health. The Law on Public Healthcare, which defines public healthcare principles, implementation methods and service structure, was approved by parliament in 2002. Amendments to the Law on Public Healthcare defined public health functions at national and local levels and paved the way for municipalities to establish public health bureaus, responsible for the provision of the local public health services, mainly health promotion, and child health [18].

In summary, it is necessary for Lithuania to continue investing in road safety promotion despite current economic hardships so that national and local cross-sectoral collaborations, sustainable long-term programmes, and primary/ secondary/tertiary traffic injury prevention can continue to yield effective results in pedestrian safety for children and young people.

Strengths and limitations. The strength of this investigation includes the combination of descriptive and time series analysis, the 40-year study period and the breakdown in road user categories. The analysis of long-term mortality trends was complicated due to the changes in the ICD over the years. However, for this study the category name for pedestrian fatal injury remained unchanged between these revisions. Statistical information in Lithuania on external causes of death has been used by WHO, as quality information for its global database from 1970 and there have been no changes in the data registration procedure since then. Thus, Lithuania's statistical information is generally considered reliable and internationally comparable $[9,19]$.

\section{Conclusions}

Pedestrian deaths in Lithuania fell significantly in the age groups 0-14 and 15-19 years. Over the post-independence period, a declining trend was found in road traffic fatalities and in pedestrian deaths in transitional Lithuania. Socioeconomic and political transformations, systematic reforms in healthcare along with sustainable preventive measures are macro-level determinants that may have contributed to this decrease. Targeted road safety measures were road traffic regulations, pedestrian education and environmentally based prevention measures. As child pedestrians are the most vulnerable group of road users, continued road safety education and promotion are recommended in order to maintain this trend, and to involve adult pedestrians in this development.

\section{Conflict of interests}

The authors declare that they have no actual or potential conflict of interest and financial conflicts in relation to this article.

Acknowledgement. Sincere thanks to Mrs. Karen Purves for her assistance with the English language.

\section{References}

1. WHO, Global Health Observatory. Road Safety.

2. Chakravarthy B, Vaca FE, Lotfipour S, Bradley D. Pediatric pedestrian injuries: emergency care considerations. Pediatr Emerg Care 2007; 23 (10): 738-44.

http://dx.doi.org/10.1097/PEC.0b013e318156acea

3. Bauer R, Steiner M. Injuries in the European Union: Statistics summary 2005-2007. Viena: KfV, EuroSafe, 2009.

4. Lunevicius R, Herbert HK, Hyder AA. The epidemiology of road traffic injuries in the Republic of Lithuania, 1998-2007. Eur J Public Health 2010; 20(6): 702-6.

http://dx.doi.org/10.1093/eurpub/ckq007

5. Sonkin B, Edwards P, Roberts I, Green J. Walking, cycling and transport safety: an analysis of child road deaths. J R Soc Med 2006; 99(8): 402-5.

http://dx.doi.org/10.1258/jrsm.99.8.402

6. Statistics Lithuania. Demographic yearbook 2011. Vilnius, 2012.

7. Strukcinskiene B, Martinkenas A, Towner E, Janson S, Andersson R. Traffic injury mortality in children in transitional Lithuania - a longitudinal analysis from 1971 to 2005. Acta Paediatr 2008; 97(3): 358-61.

http://dx.doi.org/10.1111/j.1651-2227.2007.00634.x

8. Strukcinskiene B. Unintentional injury mortality trends in children and adolescents in Lithuania between 1971 and 2005. Int J Inj Control Safe Promot 2008; 15(1): 1-8. 
http://dx.doi.org/10.1080/17457300701794212

9. Strukcinskiene B. Traffic death trends in children aged 0-14 years in Lithuania: patterns by age group. Int J Inj Control Safe Promot 2011; 18(4): 299-304. http://dx.doi.org/10.1080/17457300.2011.578216

10. Koopman SJ, Harvey AC, Doornik JA, Shephard N. Structural Time Series Analysis, Modelling, and Prediction using STAMP. London: Timberlake Consultants Press 1999.

11. Grigoriev P, Shkolnikov V, Andreev E, Jasilionis D, Jdanov D, Mesle F, Vallin J. Mortality in Belarus, Lithuania, and Russia: Divergence in recent trends and possible explanations. Eur J Popul 2010; 26: 245-74.

http://dx.doi.org/10.1007/s10680-010-9210-1

12. Popov V. Shock therapy versus gradualism reconsidered: Lessons from transition economies after 15 years of reforms. Comp Econ Stud 2007; 49: 1-31.

http://dx.doi.org/10.1057/palgrave.ces.8100182

13. Seth D, Mitis F, Racioppi F. Preventing injuries in Europe: From international collaboration to local implementation. Copenhagen: WHO Regional Office for Europe 2010.

14. WHO Regional Office for Europe. Fact sheet: Road traffic injuries in the WHO European Region: The population groups and countries most affected. Copenhagen 2004.

15. Doukas G, Olivier J, Poulos R, Grzebieta R. Exploring differential trends in severe and fatal child pedestrian injury in New South Wales, Australia (1997-2006). Accid Anal Prev 2010; 42(6): 1705-11.

http://dx.doi.org/10.1016/j.aap.2010.04.010

16. Hotz G, Kennedy A, Lutfi K, Cohn SM. Preventing pediatric pedestrian injuries. J Trauma 2009; 66(5): 1492-9.

http://dx.doi.org/10.1097/TA.0b013e31819d9c9b

17. State Enterprise Regitra. http://www.regitra.lt/lt/registrai/.

18. Murauskiene L, Janoniene R, Veniute M. van Ginneken E, Karanikolos M. Lithuania: Health systems review. Health Systems in Transition 2013; 15(2): 1-150.

19. Mathers CD, Fat DM, Inoue M, Rao Ch, Lopez AD. Counting the dead and what they died from: an assessment of the global status of cause of death data. Bull World Health Organ 2005; 83: $171-7$.

\section{PĖSČIŲJŲ MIRTINGUMO TENDENCIJOS LIETUVOJE PER KETURIS DEŠIMTMEČIUS}

B. Strukčinskienė, R. Bauer, S. Griškonis, V. Strukčinskaitė

Raktažodžiai: pėstieji, mirtingumas, tendencijos, vaikai, jaunimas.
Santrauka

Tyrimo tikslas buvo nustatyti vaikų (0-14 metų) ir paauglių (15-19 metų), kaip pėsčiųų eismo dalyvių mirtingumo tendencijas per keturis dešimtmečius pereinamojo laikotarpio Lietuvoje.

Mirčių nuo eismo traumų duomenys buvo gauti iš Statistikos Departamento prie Lietuvos Respublikos Vyriausybès ir iš Sveikatos informacijos centro archyvo. Mirtingumo tendencijų analizei buvo naudoti tiesinė regresija ir laiko eilučių moduliai. Nepriklausomybės atkūrimas (1991 metais) sietas su intervencija, jos efektu ir trendo pokyčiu, o gyventojai traktuojami kaip aiškinamasis veiksnys naudojant laiko eilučių modelius.

Tyrimo rezultatai parode, kad intervencijų poveikis (reformos bei su Nepriklausomybės atkūrimu susiję pokyčiai) pėsčiųjų mirtingumui mūsų laiko eilučių modelyje buvo labai statistiškai reikšmingas vaikams nuo 0 iki 14 metu $(p<0,001)$ ir reikšmingas jauniems žmonėms nuo 15 iki 19 metų amžiaus $(p<0,05)$. Kontrolinèse grupėse - ne pėsčiųjų eismo dalyvių ( 0 - 14 metų amžiaus grupejje) ir suaugusiųjų pėsčiujų grupejje (asmenys per 19 metų) - reikšmingų mirtingumo nuo eismo traumų pokyčių nepastebėta. 15 - 19 metų amžiaus paauglių grupejje reformų poveikis taip pat buvo reikšmingas ne pėstiesiems eismo dalyviams $(p<0,05)$. Šie rezultatai rodo, kad pokyčių ir priemonių, taikytų laikotarpiu po $\mathrm{Ne}$ priklausomybės atkūrimo, poveikis buvo reikšmingesnis vaikams, kurie dalyvavo eisme kaip pėstieji, nei suaugusiems pėstiesiems ir kitiems eismo dalyviams (ne péstiesiems).

Tyrimo metu nustatyta, kad Lietuvoje pésčiųjų eismo dalyvių mirtingumas reikšmingai sumažejo 0-14 vaikų ir 15-19 metų amžiaus paauglių grupèse. Lietuvoje laikotarpiu po Nepriklausomybės atkūrimo buvo stebimos mirtingumo nuo eismo traumų ir pėsčiųų mirtingumo mažèjimo tendencijos. Politiniai bei ekonominiai pokyčiai, sistemingos sveikatos priežiūros reformos, nuosekliai igyvendinamos prevencinès priemonès tikriausiai prisidèjo prie šio mirtingumo mažèjimo. Tikslinès eismo saugos priemonès buvo kelių eismo taisyklių tobulinimas ir pėsčiųų švietimui bei saugiai aplinkai skirtos prevencinès priemonès. Kadangi vaikai pėstieji yra labiausiai pažeidžiama eismo dalyvių grupè, rekomenduojama nepertraukiamai taikyti jų saugos mokymo ir eismo saugos stiprinimo priemones. Prevencinè veikla turi būti skirta ir suaugusiems pėstiesiems eismo dalyviams.

Adresas susirašinèti: birutedoctor@hotmail.com

Gauta 2016-10-13 